\title{
LOS SUELOS DE LA \\ DANZA. AUTOETNOGRAFÍAS ESCENIFICADAS DE FREDERICK WISEMAN
}

\section{Bárbara Díaz Ríos}

Asociación Española D+I-Danza e Investigación

\section{José Ignacio Lorente Bilbao}

Universidad del País Vasco /Euskal Herriko Unibertsitatea. Dpto. Comunicación Audiovisual y Publicidad

\section{Resumen}

El director Frederick Wiseman ha cartografiado, a lo largo de su dilatado periplo cinematográfico, la forma y la vida de las instituciones. En este particular territorio fílmico, la danza conecta el espacio institucional con el suelo prosaico y anónimo de la vida cotidiana, de la ciudad y de sus múltiples recorridos. Esas pequeñas coreografías insertas en el corazón de las instituciones presentan la fuerza disolvente de un extrañamiento a través del cual la danza provoca e imagina desbordamientos de lo sensible de una situación. Actualizan también el ejercicio de una mirada que funciona como una autoetnografía detallada de las tensiones contemporáneas.

\section{Palabras clave: WISEMAN, FREDERICK; CINE; CIUDAD; DANZA; COREOGRAFÍA; ESCENIFICACIÓN}

\section{Abstract}

Filmmaker Frederick Wiseman has been mapped, throughout his long cinematic journey, the form and the life of institutions. In this particular film territory, dance connects the institutional space with the prosaic and anonymous ground of everyday life of the city and its many tours. These samall choreographies, embedded into the heart of institutions, have the corrosive force of an estrangement, through which the dance produces and imagines overflows of the sensitive of a situation. They also update the exercise of a gaze that works as a detailed autoethnography of contemporary tensions.

Key words: WISEMAN, FREDERICK; CINEMA; CITY; DANCE; CHOREOGRAPHY; STAGING

\footnotetext{
Díaz Ríos, Bárbara \& José Ignacio Lorente Bilbao. 2015. "Los suelos de la danza. Autoetnografías escenificadas de Frederick Wiseman”. AusArt 3 (1): 21-40. DOI: 10.1387/ausart.14758
}

\section{AUSART}




\section{UNA HISTORIA NATURAL}

Frederick Wiseman (Boston, 1930) ha elaborado, a través de más de cuarenta proyectos documentales como director y productor, una minuciosa disección de las instituciones, lo que en expresión del propio autor forma una suerte de historia natural de las tensiones y conflictos que caracterizan el mundo contemporáneo. Ahora bien, ¿cuál es la naturaleza de esta historia natural a la que se refiere Wiseman y cuál el trabajo del cine, y más concretamente del cine llamado documental en la producción de esa historia?.

La idea de una historia natural bien pudiera remitir a la preceptiva del género documental según la cual, en su concepción clásica, la cámara tendría la capacidad de recoger las huellas de lo real, ya se trate de la impronta dejada en la imagen por el mundo profílmico, dispuesto ante la cámara, ya se trate de la capacidad de ésta para captar la ambivalencia de lo real (Bazin 2001), por lo que estaría restringida cualquier mediación o intervención en el registro de una situación cuyo devenir estuviera abierto a la contingencia, a la eventualidad o al azar. Sin embargo, frente a estos postulados genéricos, el cine de Wiseman procede con frecuencia a contrario, planteando juegos, paradojas y extrañamientos que lejos de naturalizar la relación de la cámara con el mundo, lo señala y en ese mismo gesto señala también el trabajo de la figura que lo enuncia y actúa tras la cámara. Ese gesto adquiere la densidad de una escritura autoetnográfica (Rusell 1999), en el momento en que en el filme se aprecia una mirada, un posicionamiento reflexivo frente al mundo documentado, a través del cual dialoga con los sujetos y acontecimientos en curso con el fin de indagar e identificar situaciones críticas, desgarros y fracturas. Un diálogo que no se resuelve mediante entrevistas o simulacros dialógicos, sino a través de interacciones durante el proceso mismo de encuentro con el mundo, para restituir aquello que las instituciones han silenciado e invisibilizado. En este cine de interacciones mostrar es montar pequeños sucesos para que asome su condición de crisis en miniatura y así "romper el silencio" (Didi-Huberman 2015, 113).

La presencia de la danza en estos juegos y extrañamientos adquiere la consistencia de un estilema, de una marca inscrita en el filme que, si bien puede ser interpretada como un indicio autoral, también constituye una suerte de ruptura o interrupción del régimen representacional de las imágenes, una rasgadura en el tejido de la convención documental que puede traducirse en una ampliación del horizonte de lecturas posibles del film. 
La inscripción de la danza en estos filmes afirma una mirada, una maniobra extraña en el desarrollo del film, a través de la cual la película performa otra mirada, la del espectador, descentrado y desplazado del pacto fiduciario reclamado por el verosímil documental. $Y$ no es extraño que estos juegos de la mirada inmersos en la historia natural del mundo contemporáneo se produzcan en los años 60 , precisamente cuando lo real y sus posibles abordajes son problematizados por las prácticas artísticas en torno a la idea de performatividad (Fischer-Lichte 2014, 47).

La mirada implicada en los filmes de Wiseman no es un mero punto de vista perceptual desde el que acceder a la representación, ni siquiera una vía de acceso cognoscitivo al universo desplegado por el film, sino más bien un posicionamiento, una forma de experimentar las situaciones, los acontecimientos y las acciones puestas en escena. La cámara se adhiere a los acontecimientos filmados, pero lejos de tratar de naturalizar su presencia, neutralizándola como si nadie hablara a través del film, al estilo de los nobody shot documentales, es frecuente observar que los sujetos reaccionan a su presencia, así como la propia cámara reacciona a sus acciones en el curso de los acontecimientos. Pero la mirada no es solamente una forma de estar y de posicionarse ante el mundo. Constituye también un compromiso de la enunciación con lo enunciado, una forma de reconstrucción y una estrategia de interpelación del sujeto al que el filme piensa y se dirige, el espectador. La mirada implicada, posicionada y reflexiva con que Wiseman reconstruye la vida de las instituciones, de su funcionamiento y coerciones, da cuenta no solo del anonimato y de lo prosaico de su acontecer, sino también de su propia participación en su curso, en el devenir incierto de los acontecimientos objeto de atención. Al programa rutinario y pautado de la disciplina institucional, Wiseman responde con la experiencia de una filmación abierta al devenir de los procesos y con la acumulación de hechos fortuitos, incongruentes, dislocados de la lógica del relato, para abrir también esa experiencia a múltiples lecturas y apropiaciones de sentido. Wiseman filma experiencias que él mismo vivencia, transformándolas en materia sensible de la relación con el mundo, disponiendo todos estos materiales como una propuesta abierta, participativa e involucrada en la problematización del mundo iniciada por el film.

Al abordar la cuestión del cine como práctica artística, Jacques Rancière distingue entre el sistema de la representación y el régimen estético de las artes, de tal forma que en tanto que en el primero se distinguían las formas de la expresión en función de la dignidad y representatividad de los temas y géneros, el régimen estético de las artes disuelve esta distinción a partir del momento en 
que lo anónimo deviene en tema del arte (Rancière 2014, 51). Se trataba del tránsito de los grandes eventos y personajes heroicos a las vidas anónimas y acontecimientos prosáicos, "para encontrar -según el autor- los síntomas de un tiempo, de una sociedad o de una civilización en los detalles ínfimos de la vida común [...], y reconstruir esos mundos a partir de sus vestigios $(2014,52)$. Lo que el filósofo denomina el régimen estético del arte propiciaría también un nuevo modo de visibilidad que desplaza el logocentrismo dominante y el poder de las palabras en favor de la interpretación de las huellas de todo tipo que han quedado inscritas en el cuerpo de los sujetos, de los espacios y de las cosas. De esta forma, lo prosáico y vulgar devienen objeto del arte, así como las condiciones de visibilidad -o de invisibilidad- de los mismos, si bien a condición de renunciar a la explicación, a la definición y a la evidencia, para plantear por el contrario, problemas, juegos o enigmas que animen y reclamen búsquedas, indagaciones y experimentación en el proceso de reconstrucción del sentido incoado por el film.

Las películas de Wiseman renuncian al cierre, a la clausura que supone la explicación de los hechos y acontecimientos para proceder a la presentación ante el espectador de los materiales filmicos en bruto, apenas organizados en la mesa de montaje para componer una situación, un contexto o simplemente, una acumulación de indicios precarios e imprecisos, desde el punto de vista de su significación. Tanto se trate de un acontecimiento en curso, al que la cámara accede en su devenir, como de un intercambio verbal, el espectador se encuentra con la sensación de asistir a una serie indicios y eventualidades, carentes de encadenamientos (crono)lógicos, ante los que es preciso actuar interpretativamente, estableciendo hilos argumentales inestables, locales y provisionales. Esta lógica inestable provoca en el espectador una intensa sensación de encontrarse inmerso en el devenir de los acontecimientos que desbaratan cualquier teleología que permita realizar anticipaciones o retrospecciones seguras de un sentido apropiado, recto, atribuible a las acciones en curso. Ante este mutismo argumental, las películas de Wiseman reclaman una atención intensificada a los pequeños detalles, a las acciones efímeras, a los gestos cotidianos y a las actitudes de los sujetos anónimos inmersos en las instituciones contemporáneas, desde el hospital y la cárcel, hasta la escuela, el laboratorio, la fábrica o el juzgado. La historia natural de Wiseman es la del registro de lo anónimo y lo prosáico que, sin embrago, guarda las huellas de los procesos y del trabajo que lo ha conformado. En ocasiones, esa historia natural entra en confrontación con la transparencia y con el borrado de las marcas dejadas por el dispositivo institucional sobre los objetos, los espacios y los cuerpos. Desde este punto de vista, la razón por la que el cine de Wiseman constituye una historia natural del mundo contemporáneo no consiste en el 
mero archivo de sus imágenes, sino en la indagación del régimen de visibilidad de esos sujetos, objetos y cuerpos desplazados, oscurecidos e invisibilizados por el propio funcionamiento del régimen institucional.

Lo relevante de este cine denominado documental, orientado a lo real, esto es, a lo que se resiste a la lógica del discurso, vendría determinado por su capacidad para vislumbrar indicios locales, fragmentarios y difusos que apuntan hacia los mecanismos de invisibilización del dispositivo institucional.

El cine documental de Wiseman juega con diferentes tipos de indicios, desde el registro de situaciones en bruto, hasta la filmación de entrevistas en vivo, en su devenir, para ofrecer una propuesta abierta a diferentes formas de pensar tanto una historia, como historias potenciales y alternativas. El cine de Wiseman no aspira a un registro fiel, ni pretendidamente objetivo de los acontecimientos. Tampoco pretende ser una guía certera de viaje por el sentido de los acontecimientos en curso, sino más bien un tránsito por los límites difusos entre la razón de los hechos y la razón de sus posibles relatos, con la expectativa de establecer nuevas conexiones entre la presentación sensible de los hechos y las formas de inteligibilidad de los mismos.

Y sería esta posibilidad abierta de pensar y de relatar historias la que expande también las capacidades de acción en el documental, tanto de la figura discursiva descentrada que actúa y organiza el enunciado fílmico, como de aquella otra figura a la que se dirige, el espectador, en tanto que sujeto político y agente histórico competente, al menos en la medida en que esos enunciados fílmicos posibilitan lecturas abiertas, organizaciones inéditas de materiales expresivos, signos e imágenes, relaciones inexploradas entre lo que vemos y lo que decimos y entre lo que hacemos y lo que podríamos hacer.

No se trata con ello de relativizar la Historia, sino de afirmar la posibilidad de otras historias y de esa forma romper la disciplina de quien puede y tiene la competencia reconocida para componer el relato de la Historia. Se trata más bien de prestar atención al modo en que el mundo histórico y social se hace visible a sí mismo a través de las marcas inscritas en su superficie, a través de lo sensible de una situación y de la práctica del relato como aspiración a construir sentido en el universo empírico de acciones opacas, complejas, aparentemente dispersas y azarosas. Tampoco se trata, con todo, de sumergir el mundo empírico en una infinidad indistinguible de historias posibles, sino de dar la posibilidad de que las historias emerjan y con ellas nuevas oportunidades de lectura de la configuración de un lugar o de una ciudad, de las marcas 
y gestos de un rostro o de la expresión silenciosa de los cuerpos, todo ello como afirmación de lo banal y de lo prosáico en confrontación con la necesidad y la causalidad que guía la economía aristotélica del ordenamiento de los acontecimientos.

La lógica precaria que sirve de sustento a estos relatos reconfigura el mapa y la fábrica de lo sensible, así como su reparto político en una situación determinada. Al afirmar la posibilidad de otras historias y lecturas de las marcas inscritas en los objetos y en los sujetos, se afirma también la posibilidad de una percepción expandida, desbordada de lo sensible de una situación. La fábrica de lo sensible une en una misma idea la actividad que fabrica y su visibilidad (Rancière 2014, 68). Saca al artesano, como al artista, del lugar asignado de trabajo, para proporcionarle un espacio en las discusiones públicas, en calidad de ciudadano deliberante.

El filme La danse, la Ópera de París (Frederick Wiseman, 2009) se desarrolla en una de las arquitecturas monumentales que caracterizan la ciudad y su historia, así como los imaginarios y las actividades que acoge esa monumentalidad. El monumento es un exceso de memoria, un objeto recubierto de escrituras de la historia que advierten al ciudadano de su disponibilidad: "puedes olvidar, yo recuerdo" (Todorov 2000). Pero el reverso de esta promesa de memoria inmediatamente accesible como relato y sentido de los grandes acontecimientos, consiste precisamente en la disipación de otras memorias, de otros relatos y otras historias, acaso disensuales y alternativas. El edificio de la Ópera de Paris no es simplemente una arquitectura noble, es la marca de la nobleza inscrita en sus formas, en su organización y en las prácticas que acoge, y también el rastro y la huella, de las que excluye e invisibiliza. En una secuencia del film, uno apicultor trabaja silenciosamente en un panal de abejas en la azotea del edificio. La naturaleza irrumpe en el espacio civilizado, noble, amenazando su legibilidad, por lo que debe permanecer oculto, apartado de la vista y del conjunto monumental. El panal representa una huella no autorizada por lo que su borrado requiere una actividad silenciosa, anónima y prosáica, la del artesano que opera sobre la historia de fondo de las prácticas que el edificio autoriza y el film, hasta ese momento, ha puesto en escena. Wiseman responde a la danza de ese espacio canónico con la contradanza que el artesano, pacientemente, ejecuta con las abejas. Pero en ese gesto fílmico, al contraponer la actividad muda del artesano con la sonoridad propia del edificio, el silencio se hace elocuente y habla, nos interpela como espectadores acerca de la actividad puesta en escena, por supuesto, pero también acerca del modo en que en esa situación la distribución política de lo sensible 
silencia el trabajo del apicultor, escondiéndolo en el anonimato de su espacio prosáico.

Al traer a escena esa fábrica de lo sensible, el film realiza una doble operación. Por un lado, señala el marco sensible, acotado, de las prácticas visibles, autorizadas por la institución dancística. Ocultar los panales supone preservar su monumentalidad de otras historias, de otras lecturas y sentidos posibles. Pero, por otro lado, al encaramar al artesano al edificio, no solo a la arquitectura, sino al edificio fílmico, al imaginario, el dispositivo que limita las prácticas y lecturas autorizadas de la danza como del cine es puesto en evidencia, mostrando las condiciones de visibilidad en las que se sustenta la monumentalidad del edificio, el arte académico y la coherencia del propio relato documental, al tiempo que el artesano, el apicultor, como el bailarín o el cineasta son restituidos al espacio público. Se trata así de incorporar el trabajo silenciado de este artesanado al espacio ciudadano y deliberativo abierto por el gesto fílmico que ha comprometido en una misma secuencia al apicultor, al bailarín y al cineasta, estableciendo entre ellos un diálogo imaginario que se hace sensible para el espectador. El trabajo silente del apicultor, como el trabajo disciplinado del cuerpo del bailarín o el trabajo invisibilizado del cineasta por la censura genérica documental, cuyos productos únicamente son apreciados en el mercado, ya se trate de la miel vendida a los turistas, del virtuosismo de la representación coreográfica o de la propia película una vez realizada, son restituidos al espacio público, expandiendo con ello las posibilidades de percepción, deliberación y juicio restringidos y custodiados por la institución de la danza.

Ese gesto quiebra la coherencia del relato monumental abriéndlo a múltiples lecturas y expectativas de sentido acaso disensuales con el sentido autorizado por el monumento. Frente a la renuncia a la memoria y la invisibilización del trabajo del artesano y del bailarín, el filme proyecta un nuevo espacio de escritura y de relato, de historias en potencia y de sentido que se transforma en un espacio político en el momento en que el pretexto monumental es intersectado por una sensibilidad expandida en la que tienen cabida voces y textos alternativos, un espacio de deliberación y de disenso en el que el espectador actúa interpretando, recurriendo a su propio archivo y memoria, y recorriendo en definitiva, con su competencia y experiencia el bosque de los signos inscritos en ese particular objeto y dispositivo urbano que es el edificio de la danza. Esta es la fábrica de lo sensible del film, el de la visibilización del trabajo de lo que ha quedado encerrado y oculto, y el de la apertura de un espacio ciudadano inédito. Esta es también la continuidad de los suelos de la danza que el film no circunscribe al espacio arquitectónico, ni a la institución, sino que se 
conecta con el espacio urbano y político, allí donde la configuración de la ciudad constituye la pantalla sobre la que se proyecta un orden social (Lefebvre 2013). En este espacio intersticial, comprometido, es donde se situa la cámara de Wiseman para realizar un trabajo de desmontaje mediante el esbozo de una escritura, aquella de la historia natural de la sociedad contemporánea construida a través de las vidas anónimas y prosáicas que habitan y cuestionan las instituciones, incluida la fábrica del propio cine.

\section{DESVIACIONES, EXTRAÑAMIENTOS, DESBORDAMIENTOS}

Jean-Luc Godard afirmaba en sus Histoire(s) du cinema (1988-1998)que el cine es un pensamiento que forma y una forma que piensa, con lo que parece llevar al territorio de lo fílmico los prolegómenos de aquella teoría del lenguaje en la que Louis Hjelmslev (1974) quiso fundamentar un nuevo tipo de investigación de las relaciones de significación, donde la forma de la expresión sale al encuentro de la forma del contenido conformando una sustancia, esto es, una manifestación particular y específica de ese encuentro. De este modo, el postulado godardiano se despliega en planos, como un origami fílmico, mediante el cual la forma del film, su forma expresiva, sale al encuentro de una forma de pensamiento que ya no puede confundirse con el referente de la imagen fílmica, ni con el mundo representado, sino que se trata más bien de un modo de pensar, de observar y de posicionarse ante el mundo.

El documental, asociado convencionalmente a una forma fílmica más cercana o respetuosa con la realidad que la ficción, ha sido objeto de un renovado interés desde el momento en que el cine de la modernidad ha puesto en cuestión los límites y modelos genéricos, así como las convenciones más asentadas acerca de los modos de representar la realidad. La renuncia a los códigos de escritura fílmica establecidos por la convención documental, tales como el verosímil o la producción de efectos de realidad, busca el establecimiento de un contrato de lectura abierto a las contingencias del proceso de desenvolvimiento del film y a las posibles lecturas en un horizonte de sentido expandido.

El documental contemporáneo impugna los efectos de realidad basados en la ilusión referencial de la imagen cinematográfica, consistente en la connivencia 
directa entre un referente y un significante, de tal forma que el significado quedaría expulsado del signo y con él la posibilidad de pensar e intervenir en su organización formal (Barthes 1970, 100). La producción de efectos de realidad en el cine documental presupone la asunción de pretextos formales acerca de la conformidad del mundo documentado con la imagen que lo documenta, pero a cambio de renunciar tanto al reconocimiento del trabajo de enunciación que se esconde tras esa supuesta conformidad, como a la asunción de una forma del contenido, de una determinada forma de pensar y concebir el mundo representado bajo la apariencia de realidad. En este sentido, el realismo implica tanto una ocultación de las opciones tomadas en el proceso de representación del mundo, como una invisibilización de los compromisos ideológicos y políticos de dicha ocultación.

El verosímil, por su parte, consiste en una reducción de lo posible, una restricción cultural y arbitraria de los posibles reales que pudieran proporcionar otras aproximaciones al mundo, de tal forma que deviene en una forma de censura ideológica e insidiosa (Metz 1970, 23).

Consecuentemente, con la refutación de las convenciones formales que en el caso del documental restringen los posibles fílmicos, no se trata tanto de buscar nuevas maneras de ilustrar una idea o pensamiento, como de elaborar a través de la experiencia fílmica un desvío entre la forma de la expresión y del contenido que abra un espacio inédito de posibilidades para pensar y poner en forma el mundo, más allá del modo en que el dispositivo documental lo ha dispuesto y conformado. De esta manera el cine puede indagar e investigar espacios inexplorados por el pensamiento y a través de ellos instaurar un ámbito privilegiado de cuestionamiento e interrogación de lo real.

En el caso de las piezas denominadas documentales de Friedrick Wiseman ese encuentro singular entre la forma expresiva del film, la forma del contenido y el posicionamiento ante el objeto de la filmación, adquiere el carácter de una experiencia del mundo, de una vivencia que se transfiere al espectador como un espacio disponible para nuevas vivencias y proyectos de sentido. Pero para poner en escena esa experiencia y vivencia posicionada Wiseman recurre a juegos irónicos, paradojas y extrañamientos, mediante los cuales produce desvíos y distanciamientos de la lectura literal del film.

En Titicut Follies (1967), la primera de las realizaciones documentales de Friedrick Wiseman, asistimos a la puesta en escena del funcionamiento cotidiano del Bridgewater State Hospital de Massachussets, una institución correccional 
destinada a la reclusión de enfermos mentales acusados de crímenes y delitos sexuales. La secuencia inicial del film presenta una situación desconcertante. Un grupo de varones, convenientemente ataviados para la ocasión, representa Strike Up the Band, un tema compuesto por George e Ira Gershwin, mediante el cual se ironiza acerca de la música militar. La ironía introduce un extrañamiento, una desviación en la relación entre el decir y lo dicho, un desvío entre la expresión y el contenido que al mismo tiempo que apunta hacia la figura de la enunciación que actúa en el texto, cuyo gesto resulta imprescindible para captar e iniciar la deriva irónica, abre un espacio inédito de sentido, un espacio potencialmente crítico y disensual con el orden del discurso. Pero, al mismo tiempo, la ironía implica también un juego de espejos entre el hacer discursivo y el saber presupuesto en el interlocutor. Reclama un trabajo interpretativo, una atención especial al uso del lenguaje.

La ironía apela a la competencia del interlocutor, movilizándola, ya se trate mediante el reconocimiento de las huellas dejadas en el texto, una especie de lectura entre líneas alejada de su literalidad, ya se trate de la movilización de la experiencia y del archivo compartido con el espectador, cuya torsión irónica deja la expectativa de sentido en entredicho. Desde esta perspectiva, la ironía presenta una innegable fuerza performativa y socializadora, debido a su capacidad para articular espacios provisionales de significado (Schultz 1962, 207), poniendo la relación con la realidad en suspenso y dejando que lo informal, lo censurado y lo desplazado emerjan, para crear complicidades, connivencias y comunidades disensuales que movilizan nuevas y en ocasiones divergentes expectativas de sentido. De esta forma, siguiendo ahora a Paul Ricoeur, el discurso irónico estimula la "configuración de significados alternativos no explícitos que el lector ha de figurarse [...], apelando a la actividad misma del receptor a través de la incoherencia textual". La ironía anima al lector a ejercer una lectura distanciada y a la vez desviada del sentido común. En el momento en que el lector advierte la posibilidad de encontrarse ante una maniobra irónica, introduce una duda, una lectura desasida de la literalidad del texto, gracias a la cual, en cada movimiento interpretativo se proyecta el sentido un paso más allá, a lo largo de una potencial cadena interminable de interpretaciones. Esta es la maniobra radical de la ironía, pues "Ilevada hasta el final, una actitud irónica puede acabar desbaratando todo significado en una serie infinita de movimientos disolventes" (De Man 1996, 235). La estrategia disolvente de la ironía adquiere entonces un nuevo giro, más radical si cabe, a partir del momento en que el lector advierte que lo que pudiera estar en cuestión no es sólo la discrepancia entre el decir y lo dicho y sus potenciales derivas de sentido, sino la posibilidad de comprensión misma, la dificultad para detener 
el juego irónico y acceder a un sentido apropiado, recto, lo que transformaría toda lectura en una inevitable desviación.

Esta capacidad corrosiva y disgregadora del sentido común que posee la ironía, constituye un hacer que mueve a hacer, reclama una actuación por parte del espectador que produce desbordamientos de las censuras genéricas del cine. Y esta movilidad del espectador para actuar en el espacio abierto por la ironía entre el decir y lo dicho, puede alcanzar una dimensión política en la medida en que apela a posibles reales que habían sido desplazados, invisibilizados, y a la posibilidad de nuevas opciones de acción en el espacio abierto entre la forma expresiva, el pensamiento y el mundo intermediado por el film.

La ironía inicial de Titicut Follies reclama la atención del espectador hacia el gesto autoral que ha dispuesto esa secuencia al comienzo del film, como puerta de acceso a su particular universo diegético, en tanto que, por el mismo hecho de señalarla, pone en entredicho la actividad de esa misma figura autoral como garante de la experiencia y del sentido del film. La ironía alcanza al trabajo de enunciación, introduciendo sospechas, cuestionamientos y connivencias que afectan al contrato fiduciario que el film documental reclama del espectador.

En la secuencia inicial nada permite diferenciar en los cuerpos uniformados de esa precaria coreografía si nos encontramos frente a vigilantes o internos y, a propósito de estos últimos, tampoco hay indicaciones fidedignas acerca de dónde se encuentran los límites de esa difusa condición de paciente-recluso que constituye la población de la institución correccional. Serán las siguientes secuencias de Titicut Follies las que se adentren en la vida del centro, a través de una rutinaria y reiterada sesión de control de los reclusos, ahora bien diferenciados entre quienes ejercen el control y la vigilancia y exhiben indiscriminadamente sus cuerpos uniformados y quienes son obligados a desvestirse y a exponer, ante la cámara, sus cuerpos desnudos. La escena presenta cierto aire grotesco que incomoda la mirada y la presencia misma del espectador. La desnudez de los cuerpos expuestos choca con la indiferenciación de la secuencia inicial en la que la puesta en escena de la confusión, entre cabaretera y carnavalesca, es confrontada ahora por el orden estricto que domina el espacio institucional. Los cuerpos silenciosos, dóciles y anónimos exhiben la desnudez como marca y expresión de ese régimen silente, autoritario y despersonalizado que invade el espacio de la institución correccional. La desnudez es la forma expresiva que apunta hacia la forma de pensamiento y las prácticas que imperan en el correccional. El propio término correccional alude 
a esa correlación formal. Corregir significa traer de nuevo a la norma lo que se había desviado de la misma, negar la diferencia, invisibilizar y silenciar la disciplina del cuerpo del recluso que no cumple condena, sino que habita un espacio y un tiempo transitorio entre la desviación y la norma. La desnudez es la marca inscrita en el cuerpo que transita entre la indisciplina y la norma. La ironía inicial adquiere así el carácter de una estrategia que actúa de cuña entre la forma anodina y convencional de la institución correccional y la forma del pensamiento que anima su función correctora, abriendo un espacio inédito entre ambas en el que el espectador experimenta un silencio elocuente a medida que los cuerpos desnudos comienzan a adquirir consistencia, presencia, bajo la forma de comportamientos y actitudes no siempre coherentes con la enajenación o la enfermedad mental. La locura, advertía Michel Foucault (2012), no es tanto un desorden de la razón como una razón del orden disciplinar que la administra y gestiona en tanto que disciplina específica del cuerpo social.

El cine de Wiseman tiene el carácter de documento de lo difuso, de un extrañamiento formal, en este caso irónico, que interpela y moviliza una mirada, a la vez posicionada y crítica con la forma genérica y convencional con que el cine documental precisamente la niega. Si el cine documental se erigió como un gesto airado frente a los excesos y distorsiones de la ficción, reclamando una ontología de la imagen en contacto con lo real, la afirmación de cualquier tipo de mirada, de subjetivación o mediación entre la imagen y el mundo no podía constituir sino una perversión de sus límites y postulados genéricos. Sin embargo, es ese precisamente el espacio en el que se mueve Wiseman al afirmar la actuación en el mismo, tanto del exceso de mirada que despliega las ironías y falacias expuestas en el film, como de aquella otra que la ironía performa como posibilidad de ejercitar una mirada posicionada y reflexiva por parte del espectador. De este modo, la torsión formal y el gesto documental operados por Wiseman adquieren el carácter de un extrañamiento, similar a aquel propuesto por Bertolt Brecht (2004), con el que el dramaturgo y poeta alemán trataba de traer a escena no ya una realidad más real si cabe con la que representar ante el espectador el drama contemporáneo, sino el gestus a través del cual el espectador se reconoce comprometido y se posiciona ante un drama que le toca, que perturba y conmueve.

La Danse, por su parte, comienza con una inmersión en la práctica de la danza que funciona a su vez como un ejercicio crítico con el pensamiento y transmisión académica del espectáculo coreográfico. El film se inicia con una serie de planos panorámicos de la capital, similares a las vistas postales con el característico sky line de la ciudad, para presentar a continuación un plano 
de la fachada del edificio de la Ópera de París, encuadrado con una cuidada simetría mediante la cual se ofrece al espectador una imagen institucional de la tradición y autoridad que éste representa. El Ballet de la Ópera de París es una institución creada en 1661 como la Acedémie Royale de Danse, por Luis XIV, apodado Rey Sol precisamente por su participación en el Ballet de la Nuit, de Jean-Baptiste Lully ataviado de Apolo, dios griego del sol y patrono de las artes. Tras estas imágenes inaugurales inmersas en el ruido de la urbe, la cámara se adentra en un espacio insólito, rompiendo la progresión institucional de la representación. Las imágenes muestran las galerías subterráneas del edificio, una suerte de espacio laberíntico acompañado de un sonido sordo, una especie de vibración que si bien posibilita una escucha también se propaga por la piel y el cuerpo del espectador generando una inquietante sinestesia o interferencia sensorial. Nuevas imágenes de artefactos y maquinaria escénica conducen hasta una sala de baile en la que una serie de bailarines ejercitan algunos pasos codificados de la danza clásica. El profesor de ballet conduce los ejercicios, apuntando, matizando o corrigiendo su ejecución, acompañado por la cámara, en un prolongado plano-secuencia que afirma así su presencia e intimidad con el curso de los acontecimientos. Una nueva sala. Un nuevo sonido. Aquí, el ballet master corrige incesantemente. Tiene en mente un modelo de movimiento que impone, con inusitada rapidez, a la pareja de bailarines para que procedan a su ejecución. El pretexto coreográfico y su código de movimientos codifican así el cuerpo de los bailarines. Nuevas secuencias ponen en escena ese cuerpo disciplinado de la danza, hasta que, de pronto, una secuencia inesperada, aparentemente ajena al ejercicio de la danza, sorprende al espectador con una presencia extraña que conduce de la disciplina de la danza a la disciplina productiva que gobierna este particular universo. La producción del espectáculo, representada por un grupo de personas que negocia, teléfono en mano, con creadores, técnicos y servicios, advierte de los objetivos, de las condiciones y de los acuerdos que rigen el funcionamiento del espectáculo y del cuerpo disciplinado por una economía simbólica y monetaria puesta al servicio de la institución.

Si la sorpresa y la desorientación constituyen las torsiones formales mediante las cuales Wiseman abre un espacio entre la factura formal del film y sus posibles lecturas, el film procede a continuación a generar una suerte de puesta en abismo mediante la reduplicación de esos ejercicios hasta la extenuación compartida por el cuerpo del bailarín y por la observación participante del espectador. Este recurso que ya había utilizado el realizador en Ballet, una pieza de cuatro horas de duración que provoca cierta sensación de cansancio y malestar en el cuerpo del espectador, es nuevamente ensayado en La danse, si bien la distribución del documental ha obligado a proyectar en dos 
partes diferenciadas lo que no es sino una única pieza documental. La performatividad de estas torsiones formales alcanza el cuerpo del espectador en el momento en que su fatiga progresa asociada a la obstinada reiteración de los ejercicios de los bailarines.

Por otra parte, si la danza moderna constituía la realización del espíritu de los tiempos, en tanto que ser para el movimiento, la extenuación del cuerpo disciplinado de la danza pone en cuestión ese principio coreográfico generando espacios de fractura y confusión por los que se cuela la búsqueda formal compartida por el film con el espectador. Así, al extrañamiento provocado por el laberinto inicial, figura mítica de la pérdida y desorientación con que el espectador se adentra en la institución de la danza, le suceden nuevos extrañamientos e incertidumbres introducidos por el modo en que la disciplina agota el cuerpo de la danza y condiciona su transmisión en tanto que adecuación estricta al pretexto coreográfico y al virtuosismo de su ejecución. El film interpela a la institución académica y a sus prácticas mediante la puesta de escena de un espacio incierto, desasosegador y disciplinado al que es invitado a incorporarse el espectador a través de la experiencia no solo interpretativa de lo que las imágenes exponen, sino también de la vivencia del esfuerzo, del agotamiento y de la desorientación. Estas imágenes no son meras representaciones del mundo de la danza, sino que toman cuerpo y se posicionan en ese espacio liminar en el que la disciplina deja las huellas del desfallecimiento en el cuerpo del bailarín, agotando la danza (Lepecki 2009) y el espectáculo de la misma y produciendo con ello un desbordamiento desde el que repensar sus pretextos y presupuestos.

National Gallery, la última de las realizaciones de Wiseman hasta el momento, finaliza con una escena insólita que afecta retrospectivamente a la experiencia y sentido del film. La mirada inquisitiva del autor realiza una inspección del espacio museístico, poniendo en escena los mecanismos relevantes del dispositivo institucional. El complejo museístico inserto en el contexto urbano y en el imaginario de la ciudadanía, se va revelando, a lo largo del film, como un mecanismo narrativo que transforma la experiencia de ese espacio y de las piezas que contiene en una coreografía milimétricamente estudiada de cuerpos en movimiento, desplazamientos, estancias e incluso errancias previstas y autorizadas por el programa espacial del museo. Pero, la experiencia museística no se reduce a una mera experiencia visual, sino que, como institución a la vez expositiva y enunciativa que es, la National Gallery dispone de una estudiada estrategia didáctica mediante la cual se crea un espacio narrativo que media entre el observador y lo observado. La visita guiada es la encargada de 
abrir ese espacio intersticial, el cual al mismo tiempo que dispone y programa el movimiento del visitante por ese espacio, genera un discurso, un relato que explica, relaciona y dramatiza la experiencia espectatorial.

El espacio museístico se transforma, pasando de ser un espacio de experiencia disponible para múltiples apropiaciones de sentido, a un espacio regulado y normalizado para asegurar una propedéutica del arte, una forma de apreciación y de consumo visual del conjunto expositivo que educa el ojo del espectador. A lo largo de la visita guiada, el espectador conducido por la lógica curatorial, encuentra en la superficie del cuadro el azogue en el que se refleja su propia mirada educada, disciplinada, sin apercibirse de que es observado precisamente por el objeto prefigurado de su mirada (Didi-Huberman 2004). Mediante la visita guiada, la experiencia estética potencial de la pintura es reemplazada por un relato que se instala entre el ojo que observa y desea comprender y el objeto orientado de la observación, de tal forma que cualquier desbordamiento de esa comprensión es colapsada por el discurso que guía la mirada y la apreciación por parte del observador. De esta forma, la pintura no devuelve otra cosa que el reflejo, más o menos satisfactorio, del deseo del observador.

Esta misma experiencia es la señalada por Wiseman, mediante la torsión formal operada en la secuencia final del film. En ella, una galería de retratos observa una cuidada coreografía interpretada por una pareja de bailarines. La danza opera aquí en un doble sentido. Por un lado, señala la paradoja del dispositivo museístico y la falacia de una supuesta libertad interpretativa por parte del espectador. La secuencia cuestiona la condición misma de ser espectador en tanto que sujeto que contempla y a la vez espera en continuo movimiento, de unas imágenes a otras, de un acontecimiento a otro, siempre en la confianza de que esa expectación será convenientemente regulada y guiada hasta su efectiva resolución. Los rostros impasibles de los retratos parecen observar la coreografía que se representa ante ellos como una expectativa de sentido que no pueden resolver y que requiere de la copresencia de otros espectadores, interpretantes activos, para despejar la incógnita planteada por la presencia extraña de la danza en el espacio museístico.

Y por otro lado, la escena en su conjunto clausura y refuta también el espacio intersticial y logocéntrico, supuestamente mediador entre el saber de quien guía la visita y representa el discurso de la institución, y quien ve negada su competencia para relacionarse abiertamente con las obras, a través de la experiencia museística. La coreografía ejecutada frente a los retratos mudos 
e inanes de la galería actualiza la coreografía museística, el pretexto que anticipa y guía la actuación del espectador colapsando ese espacio para otras apropiaciones de sentido. National Gallery invita a posicionarse ante la fábrica de lo sensible que es el museo, una institución del arte que exhibe obras y administra lecturas guiadas, autorizadas, como garantía de que el arte contiene complejos significados que solo la voz experta puede revelar y la observación disciplinada apreciar. Pero frente a esta propedéutica del arte, la película propone una experiencia insólita, un itinerario errático que aprecia en los pequeños encuentros, en los detalles y paradojas del programa museístico, las huellas de un dispositivo que ha desplazado la experiencia y la competencia del espectador, a la vez que ha invisibilizado el trabajo potencial que le corresponde en la búsqueda de sentido.

Tres pliegues fílmicos para tres desmontajes, correspondientes respectivamente al de la supuesta inmediatez de la imagen cinematográfica impugnada por la distancia irónica, en Titicut Follies; al del verosímil fílmico atribuido al género documental puesto en cuestión por la pregnancia de la forma del pensamiento disciplinario sobre el cuerpo de la danza, en La danse; y al del régimen de censura que el género fílmico opera sobre el cuerpo del film, puesto en evidencia en el momento en que las miradas silentes de los retratos colgados en el espacio expositivo parecen impugnar el juego de miradas instalado entre el pretexto coreografiado por la exposición y el cuerpo del espectador, transgrediendo con ello la pretensión de cualquier objetividad.

\section{REESCRITURAS}

Mediante la incursión de la danza en los espacios disciplinados de la enfermedad mental y la reclusión, de la tradición y transmisión coreográfica y del itinerario museístico, la mirada fílmica de Wiseman opera una disección de las instituciones que es, a su vez, una subversión de la propia mirada fílmica, tornándola reflexiva y autoconsciente. De esta forma, "el cuerpo que danza, sin dejar de ser una imagen, se convierte también en generador de discurso y dialoga con la mirada -o con el cuerpo- del espectador en una dimensión ya no absolutamente condicionada por lo sensible" (Sánchez 2013, 175). La mirada fílmica de Wiseman plantea un juego inédito con esas otras miradas mediante la ironía, mediante el desbordamiento y la apertura de espacios inéditos que activan y reclaman el archivo y la memoria inscrita en el cuerpo del especta- 
dor como una huella de luz dejada por la reclusión, por la educación o por la experiencia disciplinada que señala desplazamientos, ausencias y rechazos. La memoria, como el archivo no es una mera recuperación de algo retenido, guardado e inerte, sino que actúa como un dispositivo, como una transformación simultánea del pasado, presente y futuro, como una recreación de la economía temporal en su conjunto (Lepecki 2010, 30). Activar el archivo del espectador significa actualizar y reconfigurar esa economía temporal de selecciones, olvidos y rechazos a través de la cual se escribe y reescribe incesantemente la memoria.

El cuerpo del espectador resulta así tocado por una mirada que performa a través del extrañamiento y de la distancia. Lejos del cuerpo de la danza como espectáculo, Wiseman parece afirmar que "bailar es una acción visible de la vida" (Cunningham 2013, 185) compartida con el espectador. Todo ello hace que esta práctica fílmica se asemeje más a un ensayo filmado que a un producto conforme con las convenciones del dispositivo documental pues, si el cine de Wiseman algo documenta es precisamente el encuentro y entrecruzamiento de líneas de tensión entre cuerpos, miradas y marcos discursivos e institucionales que "actúan en y a través de ellos" (Leigh 2013, 16), lugares de intercambio, de atravesamiento (Nancy 2005). De esta forma, los cuerpos visibilizados en estos filmes son presentados como objeto de experiencia y de escrutinio de las marcas que los han dispuesto como cuerpos confinados, disciplinados, guiados u orientados.

Esta mirada supone también un modo de desterritorialización de las prácticas fílmicas en el umbral del espacio público, allí donde las instituciones permean el espacio ciudadano transformándolo en espacio de vigilancia y control de las prácticas y de los cuerpos. Aquí el territorio designa "una apropiación y ordenación del espacio como forma de dominio y disciplinamiento de los individuos" (Haesbert 2004, 94). El territorio es una red de representaciones que desembocan en comportamientos, en tiempos y espacios sociales, culturales, estéticos y cognitivos (Guattari y Rolnik 1986, 323).

Esta es la continuidad de los suelos de la danza en la que trabaja el cine de Wiseman, a un lado y otro de la apertura del espacio público y del cerramiento operado por las instituciones. Por otra parte, los cuerpos grotescos, disciplinados, ausentes o desrealizados de las películas de Wiseman constituyen también un lugar conceptual, una forma de pensamiento potencial y una práctica que piensa más allá del sujeto, a partir de "formas de subjetivación" (Bardet 
2012) de la mirada que explora y se posiciona, reflexivamente, ante los acontecimientos en curso.

El cine de Wiseman trabaja en ese contexto, inmerso en el conjunto de circunstancias en las que se inserta un hecho, estableciendo una relación directa entre la filmación y la situación en que esta se produce. Lo doméstico, lo anónimo y cotidiano de estas situaciones adquiere una carga social, política e ideológica en el momento en que el trabajo de cámara, además de registrar los procesos en su desenvolvimiento, toma posición a través de la exploración de la escena, de su experimentación y agenciamiento. Cada posición de cámara, cada encuadre y reencuadre representa, antes que realidad alguna, un punto de vista, no solo óptico y perceptual, sino también selectivo, un encuadre y un corte entre lo que accede al campo fílmico y lo que queda relegado fuera de campo, entre lo que potencialmente puede acceder a él y lo que es desechado, silenciado, olvidado. $Y$ es precisamente este contexto abierto y procesual, en el que opera la mirada, el que hace del cine de Wiseman una práctica contextual por la que el realizador se anexiona la realidad con el fin de intervenir sobre ella, "haciendo valer el potencial crítico y estético de las prácticas artísticas -entre ellas el cine- más volcadas en la presentación que en la representación" (Ardenne 2006, 25). Tejer el texto fílmico con la realidad, con la situación y el contexto significa poner atención a esa realidad no como cosa, sino como campo de maniobras fílmicas que abren espacios potenciales de disenso con el modo en que se han institucionalizado las prácticas sociales y las propias prácticas fílmicas. Y si el cine pone atención a esas relaciones entre espacios, contextos y formas de habitarlos es precisamente para desbordar la percepción de los hechos y advertir en ellos, visibilizando la fábrica de lo sensible de esa situación, cómo son anticipados por un determinado contexto, cómo son gestionados, relegados o privilegiados por las instituciones y por los dispositivos sociales que las sostienen, incluido el cine y la expectativa de lectura en que ha sido educado el espectador.

Esta práctica fílmica contextual, posicionada y reflexiva produce en el cine de Wiseman un doble registro, el de la continuidad de los suelos de la danza que prolifera por el espacio urbano y sus instituciones, y el de una experiencia autoetnografiada, una escritura que se expresa a través de la mirada con que el realizador escenifica y desborda, mediante juegos y paradojas y a través de la danza, el objeto invisibilizado de la representación. 


\section{Referencias}

Ardenne, Paul. 2006. Un arte contextual: La creación artística en medio urbano, en situación de intervención, de participación. Murcia: Cendeac

Bardet, Marie. 2012. Pensar con mover: Un encuentro entre danza y filosofía. Buenos Aires: Cactus

Barthes, Roland et al. 1970. Lo verosímil. Buenos Aires: Tiempo Contemporáneo

Bazin, André. (1958-61) 2001. ¿Qué es el cine? Madrid: Rialp

Brecht, Bertolt. (1933-47) 2004. Escritos sobre el teatro. Madrid: Alba Editorial

Català Domènech, Josep M. 2000. "El film-ensayo: La didáctica como una actividad subversiva". Archivos de la Filmoteca: Revista de Estudios Históricos sobre la Imagen 34: 79-97

Cunningham, Merce. 2013. “Espacio, tiempo y danza”. Pp. 183-187 en Lecturas sobre danza y coreografía, Isabel de Naverán y Amparo Écija, eds. Madrid: Artea

De Man, Paul. 1996. El concepto de ironía. Valencia: Episteme

Didi-Huberman, Georges. 2014. Blancas inquietudes. Santander: Contracampo

Fischer-Richter, Erika. 2014. Estética de lo performativo. Madrid: Abada

Font, Domènec. 2012. Cuerpo a cuerpo: Radiografías del cine contemporáneo. Barcelona: Círculo de lectores

Foucault, Michael. 2012. Vigilar y castigar. México: Siglo XXI

Guattari, Félix y Suely Rolnik. 1986. Micropolítica: Cartografías do desejo. Petrópolis, Brasil: Vozes

Haesbaert, Rogério. 2004. O mito da desterritorializaçao: Do "fin dos territorios" á multiterritiralidade. Río de Janeiro: Bertrand

Hjelmslev, Louis. 1974. Prolegómenos a una teoría del lenguaje. Madrid: Gredos

Lefebvre, Henri. (1974) 2013. La producción del espacio. Madrid: Capitán Swing

Lepecki, André. 2010. "The body as archive: Will to re-enact and the afterlives of dances". Dance Research Journal 42(2): 28-48

- 2009. Agotar la danza: Performance y política del movimiento. Traducción de Antonio Fernández Lera. Alcalá: Universidad de Alcalá de Henares

Liddell, Angélica. 2014. El sacrificio como acto poético. San Sebastián: Continta me Tienes

Monnier, Mathilde, Jean-Luc Nancy y Claire Denis. 2005. Allitérations: Conversations sur la danse. Paris: Galilée

Ortega, María Luisa, coord. 2005. Nada es lo que parece: Falsos documentales, hibridaciones y mestizajes del documental en España. Madrid: Ocho y Medio

Prelorán, Jorge. 2006. El cine etnobiográfico. Buenos Aires: Catálogos

Renov, Michael. 2004. The subject of documentary. Minneapolis: University of Minnesota

Ricoeur, Paul. 1976. Interpretation theory: Discourse and the surplus of meaning. Fort Worth: Texas University Press

Rosset, Clement. 2004. Lo real: Tratado de la idiotez. Madrid: Pre-textos 
Rusell, Catherine. 1999. "Autoethnography: Journeys of the Self”. Pp. 275-314 en Experimental ethnography: the work of film in the age of video. Durham: Duke University Press

Sánchez Martínez, José Antonio. 2013. "La mirada y el tiempo”. Pp. 175-183 en Lecturas sobre danza y coreografía, Isabel de Naverán y Amparo Écija, eds. Madrid: Artea

Schutz, Alfred. (1945) 1962. "On multiple realities". Pp. 207-59 en Collected Papers. La Haya: Martinus Nijhoff

Todorov, Tzvetan. 2000. Los abusos de la memoria, Buenos Aires: Paidós

Weinrichter López, Antonio A. 2004. Desvíos de lo real: El cine de no ficción. Madrid: T\&B

Weinrichter López, Antonio A. et al. 2007. La forma que piensa: Tentativas en torno al cine-ensayo. Iruñea-Pamplona: Gobierno de Navarra 